\title{
Acute and sub-acute toxicity effects of lambda-cyhalothrin in chicks
}

\author{
S.A. Alrawe $\odot$ and M.H. Alzubaidy $\odot$ \\ Department of Physiology, Biochemistry and Pharmacology, College of Veterinary Medicine, University of Mosul, Mosul, Iraq
}

\begin{tabular}{l} 
Article information \\
\hline Article history: \\
Received March 07, 2021 \\
Accepted May 20, 2021 \\
Available online November 24, 2021 \\
\hline Keywords: \\
Lambda-cyhalothrin \\
Chicks \\
Toxicity effects \\
LD 5 \\
\\
\hline Correspondence: \\
M.H. Alzubaidy \\
munahazim@uomosul.edu.iq
\end{tabular}

\begin{abstract}
A Lambda-cyhalothrin (LTC) is classified as a synthetic type II pyrethroids, available in the local market, used to eliminate insects, which is widely used for spraying homes. This study aims to reveal the acute and subacute toxic effects of LTC in chicks as a biological model. The acute (LD50) by up and down method recorded through $24 \mathrm{hrs}$. The signs and toxicity scores were estimated, the sub-acute toxicity effects of LTC in the openfield activity and tonic immobility test, body-weight and histopathological effects were recorded. The oral $L T C \mathrm{LD}_{50}$ in chicks was $228.5 \mathrm{mg} / \mathrm{kg}$. Oral administration of LTC at doses $57.12,114.25$, and $171.36 \mathrm{mg} / \mathrm{kg}$, which represented $25 \%, 50 \%$, and $75 \%$ of LD50 respectively, caused signs of toxicity such as depression with wing dropping, feathered by closed eyelids, gasping, and recumbency. LTC causes a significant decrease in chick's weight, locomotor activity in the open field activity represented by increase latency to move, and decrease the number of lines crossed. The liver and brain show histopathological changes such as congestion, focal infiltration of mononuclear cells, hemorrhage, coagulative necrosis, and vasogenic edema. In the brain, the lesion was represented by shrunken in purkinji, demyelination of axon and hyper atrophy of astrocyte, the lesion was more severe in both organs when exposed to a high concentration and for longer periods. Our results demonstrated that LCT has a moderate toxicity in chicks, and causes behavioral and histological toxic effects, especially with sub-acute toxicity. Therefore, we do not recommend using it, and restricted application in homes and agriculture.
\end{abstract}

DOI: 10.33899/ijvs.2021.129674.1678, (CAuthors, 2022, College of Veterinary Medicine, University of Mosul.

This is an open access article under the CC BY 4.0 license (http://creativecommons.org/licenses/by/4.0/).

\section{Introduction}

Lambda-cyhalothrin (LTC) is amongst the intensively used. Synthetic type II pyrethroids. It is a member of the new generation pyrethroids family (1). LTC has been considered as the favorite insecticide since it is relatively safe in terms of toxicity. It has been used for a broad range of crops, such as cotton and a variety of vegetables, to prevent parasites of plants. Furthermore, LTC has also been implemented in indoor usage for many purposes such as controlling mosquitos and other insects $(1,2)$. LTC is utilized to control ticks, cockroaches, flies, and other disease vectors. Therefore, it may contribute to environmental hazards through the presence in water of rivers and streams, leading to poisoning of aquatic organisms, animals, and human. In addition, human poisoning with pyrethroids by eating contaminated beef has been recorded (2-4). Despite of LTC is moderately toxic for mammals $(5,6)$. In fish, aquatic invertebrates, and bees, high toxicity has been observed. Lambda-cyhalothrin might be lethal at low concentrations in chicks, species (7). The lipophilic nature is important for the toxicity of lambdacyhalothrin (8). As a result, pyrethroids are easily absorbed through membranes of the gastrointestinal system and respiratory system due to the high fat solubility, which also makes them easier to be stored in body fats, kidneys, liver, peripheral and central nervous systems (9). The liver is the organ responsible for metabolizing lambda-cyhalothrin and 
most the chemical compounds that enter the body through cleaving hydrolytic ester and oxidative pathways via the cytochrome P450 (CYP450), which yield reactive oxygen species (ROS). The excess production of ROS causes oxidative stress and cellular damage (10). Lambdacyhalothrin's acute toxic impact is neurotoxicity. It impairs the production and transmission of nerve impulses by interfering with sodium channels in neurons. This action interferes with the nerve function of insects, causing loss of muscle control, paralysis, and death $(9,10)$. Nerve fibers are the targets of the pyrethroids. They can impair the function of proteins regulating $\mathrm{Na}^{+}$channels $(<0.6 \%)$, in addition, they presumably affect both chloride and calcium channels, thereby impairing the nerve functions. As a result, the insect shows different bursts -ranging from short to longdue to repetitive signals discharge and nerve depolarization (10).

Because the Lambda-cyhalothrin is cheap and available in the markets of Mosul, it is widely used for spraying at homes therefore, our current study sought to investigate the acute and subacute toxic effects in chicks.

\section{Materials and methods}

\section{Animals}

We used 112 mix-breed Ross 7-28 days old broiler chicks of both males and females. They given water and ration ad libitum and were kept in batches of 20 to 30 chicks at a temperature of $30^{\circ} \mathrm{C}$ to $34^{\circ} \mathrm{C}$, with constant lighting.

\section{Insecticides and chemicals}

Commercial pyrethroids insecticidal concentrate solutions of the lambda- cyhalothrin $5 \%$ manufactured by JU. AgriSciences Pvt. Ltd. India. The dose was $5 \mathrm{ml} / \mathrm{kg}$ administered orally.

\section{Acute $\mathrm{LD}_{50}$ of lambda-cyhalothrin}

We determined the acute oral median lethal dose (LD50) of lambda-cyhalothrin in broiler chicks using the up and down method (11). The signs of toxicity were recorded for two hours and then the lethality 24-hour was recorded, using 8 chicks for this experiment.

\section{Acute toxicity signs of lambda-cyhalothrin in chicks}

We used 32 chicks age 7-14 days, of body weight 128$203 \mathrm{~g}$, divided into four groups 8/group randomly. The dosages of lambda-cyhalothrin 0 control group, 57.12, $114.25,171.36 \mathrm{mg} / \mathrm{kg}$ orally represented $25,50,75 \%$ of $\mathrm{LD}_{50}$. The signs of poisoning were recorded within two hours. The severity of toxicosis was scored as reported earlier (12). The onset, signs, and toxicity score of lambdacyhalothrin acute toxicity was evaluated for all groups.

\section{Effect of lambda-cyhalothrin on open-field activity and tonic immobility}

Twenty- four chicks were divided into four groups (6/group) randomly. The chicks were administered distilled water at $5 \mathrm{~mL} / \mathrm{kg}$ or lambda-cyhalothrin at 11.42, 22.85, $45.7 \mathrm{mg} / \mathrm{kg}$ orally these represented 5,10 and $20 \%$ of $\mathrm{LD}_{50}$. from the first day to the twenty-eighth day, measurements were taken on the seventh, fourteenth, and twenty- eighth days. The chicks were checked for behavior during 3 minute via open-field activity as mentioned earlier (13-16). Each chick was used for the tonic immobility behavioral paradigm, after the open-field activity test (13-16).

Effects of lambda-cyhalothrin on body weight of chicks:

Twenty- four chicks were weighed from the first day of dosing of lamda-cyhalothrin to the twenty-eighth day, and the average weights were taken on the seventh, fourteenth and twenty - eighth day.

\section{Histological effects of lambda-cyhalothrin in the chicks.}

The treated chicks with lambda-cyhalothrin at $0,5,10$ and $20 \%$ of $\mathrm{LD}_{50} \mathrm{mg} / \mathrm{kg}$ orally on the seventh, fourteenth, and twenty- eighth day were an incision was made, and 1 $\mathrm{cm}$ of liver and brain were obtained. Tissues were fixed using $10 \%$ neutral buffer formalin for 72 hours. Fixed tissues were processed according to the standard histopathological protocol, and thick slices 5-6 $\mu \mathrm{m}$ were stained using hematoxylin and eosin (17). Sections were examined under a light microscope, and images were taken using digital camera (HDCM-5).

\section{Statistical analysis}

Data were analyzed using one-way ANOVA, and then the significance was worked out via the least significant test. The Fisher test was used to analyze the frequency data. Non- parametric data were analyzed via Man Whitney test, using significance level at $\mathrm{P}<0.05$ (18).

\section{Results}

\section{Acute LD50 of lambda-cyhalothrin in chicks}

The acute LD50 of lambda-cyhalothrin was $228.5 \mathrm{mg} / \mathrm{kg}$ orally by up and down technique (Table 1).

The signs of poisoning are closed eyelids, depression with wing dropping, feathered, gasping, and immobility, recumbency, followed by death (Table 1 ).

\section{Acute toxicity signs of lambda-cyhalothrin in chicks}

Toxicity scores and acute toxicity signs of lambdacyhalothrin are shown in table 2. Further, lambdacyhalothrin at $57.12,114.25$ and $171.36 \mathrm{mg} / \mathrm{kg}$ orally that represented 25,50 and $75 \%$ of acute LD50, cause signs of poising in the chicks represented by closed eyelids, depression with wing dropping, feathered, defecation, twisting of the head, gasping, and recumbency. 
Table 1: The acute $\mathrm{LD}_{\mathbf{5 0}}$ of lambda-cyhalothrin in chicks for 24 hour

\begin{tabular}{ll}
\hline Value & Results \\
\hline $\mathrm{LD}_{50}(\mathrm{mg} / \mathrm{kg})$ & 228,5 orally \\
Range of doses $(\mathrm{mg} / \mathrm{kg})$ & $250-125=125$ \\
First dose $(\mathrm{mg} / \mathrm{kg})$ & 125 \\
final dose $(\mathrm{mg} / \mathrm{kg})$ & 250 \\
Increase or decrease in the dose $(\mathrm{mg} / \mathrm{kg})$ & 25 \\
Number of chicks used & $8($ OOOOXOOX) \\
Signs of toxicity & Closed eyelids, depression with wing dropping, feathered, gasping, \\
Onset of toxicity (minutes) & immobility, recumbency, followed by death. \\
\hline
\end{tabular}

*X: died; O: survived

Table 2: Toxicity signs and toxicity scores of lambda-cyhalothrin in chicks

\begin{tabular}{lcccc}
\hline \multirow{2}{*}{ Parameters } & $\begin{array}{c}\text { Control } \\
\text { (distilled water) }\end{array}$ & $57.12 \mathrm{mg} / \mathrm{kg}$ & $114.25 \mathrm{mg} / \mathrm{kg}$ & $171.36 \mathrm{mg} / \mathrm{kg}$ \\
\cline { 2 - 5 } & 0.00 & $4.25 \pm 1.27 * \mathrm{a}$ & $1.50 \pm 0.18^{*}$ & $2.25 \pm 0.41^{*}$ \\
\hline Onset of toxicity signs (minutes) & 0.00 & $50^{*}$ & $63^{*}$ & $75^{*}$ \\
Depression and feathered & 0.00 & $63^{*}$ & $50^{*}$ & $88^{*}$ \\
Closed eyelids & 0.00 & $88^{*}$ & $50^{*}$ & $75^{*}$ \\
Wing drooping & 25 & $75^{*}$ & $88^{*}$ & $88^{*}$ \\
Defecation & 0.00 & 38 & 25 & 25 \\
Twisting of the head & 0.00 & $100^{*}$ & $88^{*}$ & $100^{*}$ \\
Recumbency & 0.00 & 25 & 38 & $88^{*}$ \\
Gasping & 1 & $19^{*}$ & $18^{*}$ & $23^{*}$ \\
Toxicity scores & &
\end{tabular}

Value means \pm standard error. *Significantly dissimilar from the first group (control group) at $\mathrm{P}<0.05$. n: 8 chicks.

\section{Sub-acute effects of lambda-cyhalothrin on body weight of chicks}

Lambda -cyhalothrin at dose $11.42,22.85,45.7 \mathrm{mg} / \mathrm{kg}$ orally that represented 5,10 and $20 \%$ of the acute $\mathrm{LD}_{50}$, cause significant decrease in the body weight of the chicks on the seventh, fourteen and twenty-eight days compared to the control group (Tables 3-5).

Sub-acute effects of Lambda-cyhalothrin on the openfield activity and tonic immobility test.

Table 6 shows the effects of lambda-cyhalothrin on chicks treated with $11.42,22.85$ and $45.7 \mathrm{mg} / \mathrm{kg}$ orally, on the $7^{\text {th }}$ day of treatment, represented by significant drop in the number of line crossed, number of jumping and number of defecation compare with control group. The dose of lambda-cyhalothrin $45.7 \mathrm{mg} / \mathrm{kg}$ causes significant increase in the period to move in the arena compared to the control. Table 7 shows the effects of lambda-cyhalothrin in chicks treated with $11.42,22.85$ and $45.7 \mathrm{mg} / \mathrm{kg}$ orally on the $14^{\text {th }}$ day of treatment represented by a significant decrease in the number of line crossed, number of jumping and number of defecation in comparison with the control group and increase in the period to move in the arena compared to control group. Table 8 shown the effects of lambdacyhalothrin in chicks treated with $11.42,22.85$, and 45.7 $\mathrm{mg} / \mathrm{kg}$ orally on the $28^{\text {th }}$ day of treatment represented by a significant decrease in the number of line crossed compared to the control group at the dose $11.42 \mathrm{mg} / \mathrm{kg}$ and the dose of $45.7 \mathrm{mg} / \mathrm{kg}$ caused increase in the period to move in the arena compared to control group. Tables 6-8 shows the effects of lambda-cyhalothrin on chicks treated with 11.42, 22.85 , and $45.7 \mathrm{mg} / \mathrm{kg}$ orally, the dose 45.7 causes a significant elevation in the period of tonic immobility test regarding to the control on the $7^{\text {th }}, 14$ th and $28^{\text {th }}$ days of treatment. On the $28^{\text {th }}$ day, all doses cause an increase in the period of immobility test.

\section{Sub-acute effects of Lambda-cyhalothrin on the histopathological in the liver and brain}

Figure 1 shows the microscopic examination of liver in chicks treated with lambda-cyhalothrin at dose $11.42 \mathrm{mg} / \mathrm{kg}$ orally from 1-7 days of age show congestion and focal infiltration of mononuclear cells. We show in figure 2 the microscopic examination of liver in chicks treated with lambda-cyhalothrin at dose $22.85 \mathrm{mg} / \mathrm{kg}$ orally from $1-7$ days of age fatty changes, with infiltration of inflammatory cells and hemorrhage. Whereas figure 3 shows the microscopic examination of liver in chicks treated with 45.7 $\mathrm{mg} / \mathrm{kg}$ of lambda-cyhalothrin from 1-7 days of age coagulation necrosis, infiltration of inflammatory cells and hemorrhage. Figure 4 microscopic examination of liver in chicks treated with lambda-cyhalothrin at dose $11.42 \mathrm{mg} / \mathrm{kg}$ 
orally from 1-14 days of age recent thrombus, vasogenic edema and vasculitis. In figure 5 microscopic examination of liver in chicks treated with lambda-cyhalothrin at dose $45.7 \mathrm{mg} / \mathrm{kg}$ orally from 1-14 days of age show recent thrombus, edema, and thickness of the wall of a portal artery and coagulative necrosis. The lesion is more severe in the liver treated with lambda-cyhalothrin at doses 11.41, 22.85 and $45.7 \mathrm{mg} / \mathrm{kg}$ orally from the age of 1-28 days, with the occurrence of the lesion shown in figure 6 when treating chicks at dose $22.85 \mathrm{mg} / \mathrm{kg}$ represented by hyperplasia of epithelial of the bile duct, edema, and dilation of the sinusoid. In the brain treated with lambdacyhalothrin at dose $11.42 \mathrm{mg} / \mathrm{kg}$ orally from 1-7 days of age show shrunken in Purkinje cells, congestion and vasogenic edema (Figures 7 and 8). In the pia meter section, we show a liquefactive necrosis, infiltration of inflammatory cells, congestion and necrotizing of blood vessels in the chicks treaded at dose $45.7 \mathrm{mg} / \mathrm{kg}$, so the lesion was more sever in the dose $22.85 \mathrm{mg} / \mathrm{kg}$ (Figures 9 and 10). In figure 11, the microscopic examination of brain in chicks treated with lambda-cyhalothrin at dose $11.42 \mathrm{mg} / \mathrm{kg}$ orally from 1-14 days of age hyper atrophy of astrocyte, proliferation of astrocyte, demyelination of axon, vasogenic edema and infiltration of inflammatory cells. When performing histological examination of the chick's brain, treated with the doses 22.85 and $45,7 \mathrm{mg} / \mathrm{kg}$ from 1-14 days of age, there are patches hemorrhage, sever infiltration of inflammatory cells, edema and liquefactive necrosis, more sever with dose $45.7 \mathrm{mg} / \mathrm{kg}$ in figure 12 . We show in figure 13 vascular degeneration in astrocyte, lysis of neuronal cell body and liquefactive necrosis in chicks treated with dose $11.42 \mathrm{mg} / \mathrm{kg}$ from 1-28 days of age. Whereas the chicks exposed to higher concentration of the lambda-cyhalothrin showed the histological lesions proven when performing a microscopic examination of the brain of the treated chicks for 28 days; profliration of oligodendroglia cells with longitudinal arrangement, hyper atrophy of astrocytes, demyelination of neuron axon, vasogenic edema and liquefactive necrosis (Figure 13).
Table 3: Bodyweight of chicks treated with lambdacyhalothrin at dose 5,10 and $20 \%$ of $\mathrm{LD}_{50}$ at 7 days

\begin{tabular}{lc}
\hline Dose $\mathrm{mg} / \mathrm{kg}$ & Bodyweight $(\mathrm{g})$ \\
\hline Control group & $125.3 \pm 5.2$ \\
$11.42 \mathrm{mg} / \mathrm{kg}(5 \%)$ & $101.0 \pm 4.1^{*}$ \\
$22.85 \mathrm{mg} / \mathrm{kg}(10 \%)$ & $99.6 \pm 1.8^{*}$ \\
$45.7 \mathrm{mg} / \mathrm{kg}(20 \%)$ & $98.0 \pm 5.3^{*}$ \\
\hline
\end{tabular}

Value means \pm standard error. *Significantly dissimilar from the first group (control group) at $\mathrm{P}<0.05$. n: 8 chicks.

Table 4: Bodyweight of chicks treated with lambdacyhalothrin at dose $5 \%, 10 \%$ and $20 \%$ of $\mathrm{LD}_{50}$ at 14 days

\begin{tabular}{lc}
\hline Dose $\mathrm{mg} / \mathrm{kg}$ & Bodyweight $(\mathrm{g})$ \\
\hline Control group & $365.6 \pm 19.0$ \\
$11.42 \mathrm{mg} / \mathrm{kg}(5 \%)$ & $301.3 \pm 10.8^{*}$ \\
$22.85 \mathrm{mg} / \mathrm{kg}(10 \%)$ & $287.5 \pm 12.7^{*}$ \\
$45.7 \mathrm{mg} / \mathrm{kg}(20 \%)$ & $253.5 \pm 24.1^{*}$ \\
\hline
\end{tabular}

Value means \pm standard error. *Significantly dissimilar from the first group (control group) at $\mathrm{P}<0.05$. n: 8 chicks.

Table 5: Bodyweight of chicks treated with lambdacyhalothrin at dose $5 \%, 10 \%$ and $20 \%$ of $\mathrm{LD}_{50}$ at 28 days

\begin{tabular}{lc}
\hline Dose $\mathrm{mg} / \mathrm{kg}$ & Bodyweight $(\mathrm{g})$ \\
\hline Control group & $843.0 \pm 38.8$ \\
$11.42 \mathrm{mg} / \mathrm{kg}(5 \%)$ & $750.1 \pm 26.0^{*}$ \\
$22.85 \mathrm{mg} / \mathrm{kg}(10 \%)$ & $599.5 \pm 107.4^{*}$ \\
$45.7 \mathrm{mg} / \mathrm{kg}(20 \%)$ & $603.0 \pm 35.2^{*} \mathrm{ab}$ \\
\hline
\end{tabular}

Value means \pm standard error. * Significantly dissimilar from the first group (control group) at $\mathrm{P}<0.05$. a significantly dissimilar compared to the second group (5\% of $\left.\mathrm{LD}_{50}\right)$ at $\mathrm{P}<0.05$. b significantly dissimilar compared to the third group (10\% of $\left.\mathrm{LD}_{50}\right)$ at $\mathrm{P}<0.05$. n: 6 chicks.

Table 6: Effects of lambda-cyhalothrin in 3-minutes open field activity and tonic immobility test in the $7^{\text {th }}$ day from administration

\begin{tabular}{lcccc}
\hline Variables & Control & $5 \%$ of $\mathrm{LD}_{50}$ & $10 \%$ of $\mathrm{LD}_{50}$ & $20 \%$ of $\mathrm{LD}_{50}$ \\
\hline Latency to move / seconds & $6.50 \pm 3.98$ & $58.83 \pm 22.20$ & $57.00 \pm 19.73$ & $66.50 \pm 19.40^{*}$ \\
Lines crossed & $36.16 \pm 6.61$ & $5.83 \pm 1.07^{*}$ & $2.500 \pm 0.72^{*}$ & $4.67 \pm 1.56 *$ \\
Escape jumps & $3.50 \pm 0.88$ & $0.00 \pm 0.00 *$ & $0.00 \pm 0.00^{*}$ & $0.00 \pm 0.00^{*}$ \\
Distress calls & $3.00 \pm 0.00$ & $2.83 \pm 0.17$ & $3.00 \pm 0.00$ & $3.00 \pm 0.00$ \\
Pecking & $0.00 \pm 0.00$ & $3.00 \pm 1.69$ & $2.66 \pm 10.46 *$ & $0.00 \pm 0.00$ \\
Defecations & $1.00 \pm 0.00$ & $0.50 \pm 0.22^{*}$ & $0.33 \pm 0.21 *$ & $1.00 \pm 0.00 \mathrm{ab}$ \\
Tonic immobility / seconds & $11.00 \pm 1.36$ & $13.33 \pm 2.31$ & $34.00 \pm 3.67$ & $39.16 \pm 17.67 *$ \\
\hline
\end{tabular}

Value means \pm standard error. *Significantly dissimilar from the first group (control group) at $\mathrm{P}<0.05$. a significantly dissimilar compared to the second group $\left(5 \%\right.$ of $\left.\mathrm{LD}_{50}\right)$ at $\mathrm{P}<0.05$. b significantly dissimilar compared to the third group $(10 \%$ of $\left.\mathrm{LD}_{50}\right)$ at $\mathrm{P}<0.05$. n: 6 chicks. 
Table 7: Effects of lambda-cyhalothrin in 3-minutes open field activity and tonic immobility test in the $14^{\text {th }}$ day from administration

\begin{tabular}{lcccc}
\hline Variables & Control & $5 \%$ of $\mathrm{LD}_{50}$ & $10 \%$ of $\mathrm{LD}_{50}$ & $20 \%$ of $\mathrm{LD}_{50}$ \\
\hline Latency to move / seconds & $3.00 \pm 1.06$ & $27.83 \pm 12.95^{*}$ & $34.67 \pm 4.26 *$ & $6.67 \pm 1.35 \mathrm{ab}$ \\
Lines crossed & $12.00 \pm 3.85$ & $3.83 \pm 0.94^{*}$ & $4.66 \pm 0.61 *$ & $6.83 \pm 1.24$ \\
Escape jumps & $2.00 \pm 0.00$ & $0.00 \pm 0.00 *$ & $0.00 \pm 0.00 *$ & $0.00 \pm 0.00^{*}$ \\
Distress calls & $3.00 \pm 0.00$ & $2.50 \pm 0.55$ & $1.83 \pm 0.31$ & $1.50 \pm 0.22$ \\
Pecking & $0.00 \pm 0.00$ & $3.00 \pm 0.00^{*}$ & $3.00 \pm 0.00^{*}$ & $3.00 \pm 0.00^{*}$ \\
Defecations & $0.50 \pm 0.22$ & $0.33 \pm 0.21$ & $0.33 \pm 0.21$ & $0.50 \pm 0.22$ \\
Tonic immobility / seconds & $20.33 \pm 5.85$ & $22.50 \pm 6.14$ & $17.00 \pm 2.86$ & $38.50 \pm 7.20^{*} \mathrm{ab}$ \\
\hline
\end{tabular}

Value means \pm standard error. *Significantly dissimilar from the first group (control group) at $\mathrm{P}<0.05$. a significantly dissimilar compared to the second group $\left(5 \%\right.$ of $\left.\mathrm{LD}_{50}\right)$ at $\mathrm{P}<0.05$. b significantly dissimilar compared to the third group (10\% of $\left.\mathrm{LD}_{50}\right)$ at $\mathrm{P}<0.05$. $\mathrm{n}: 6$ chicks.

Table 8: Effects of lambda-cyhalothrin in 3-minutes open field activity and tonic immobility test in the $28^{\text {th }}$ day from administration

\begin{tabular}{lcccc}
\hline Variables & Control & $5 \%$ of $\mathrm{LD}_{50}$ & $10 \%$ of $\mathrm{LD}_{50}$ & $20 \%$ of $\mathrm{LD}_{50}$ \\
\hline Latency to move / seconds & $12.83 \pm 3.88$ & $10.67 \pm 3.73$ & $20.17 \pm 2.84$ & $8.17 \pm 3.21 \mathrm{a}$ \\
Lines crossed & $3.33 \pm 0.48$ & $10.67 \pm 3.73^{*}$ & $5.33 \pm 2.36$ & $7.00 \pm 1.98$ \\
Escape jumps & $0.0 \pm 0.00$ & $0.0 \pm 0.00$ & $0.00 \pm 0.00$ & $0.00 \pm 0.00$ \\
Distress calls & $2.50 \pm 0.50$ & $2.16 \pm 0.31$ & $1.67 \pm 0.21$ & $1.50 \pm 0.22$ \\
Pecking & $3.00 \pm 0.00$ & $2.50 \pm 0.22$ & $1.33 \pm 0.21^{*}$ & $1.00 \pm 0.00^{*}$ \\
Defecations & $0.00 \pm 0.00$ & $0.00 \pm 0.00$ & $0.17 \pm 0.16$ & $0.00 \pm 0.00$ \\
Tonic immobility / seconds & $42.67 \pm 9.30$ & $21.17 \pm 2.38^{*}$ & $20.00 \pm 4.91^{*}$ & $45.17 \pm 8.61^{*}$ \\
\hline
\end{tabular}

Value means \pm standard error. *Significantly dissimilar from the first group (control group) at $\mathrm{P}<0.05$. a significantly dissimilar compared to the second group $\left(5 \%\right.$ of $\left.\mathrm{LD}_{50}\right)$ at $\mathrm{P}<0.05$. b significantly dissimilar compared to the third group $(10 \%$ of $\left.\mathrm{LD}_{50}\right)$ at $\mathrm{P}<0.05$. n: 6 chicks.

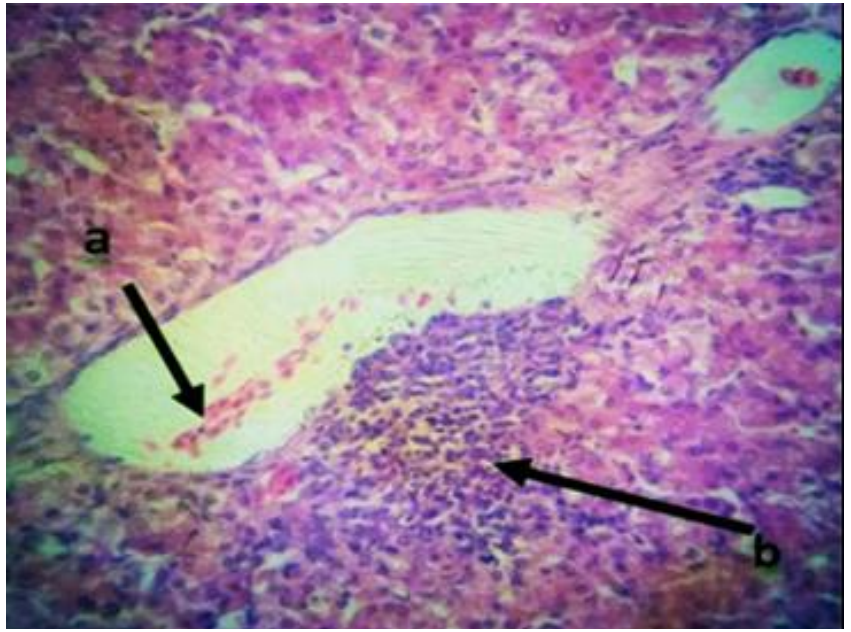

Figure 1: Microscopic examination of liver in chicks treated with lambda-cyhalothrin at dose $11.42 \mathrm{mg} / \mathrm{kg}$ orally from 1 7 days of age show a: congestion b: focal infiltration of mononuclear cells. HE, 40×1.1X.

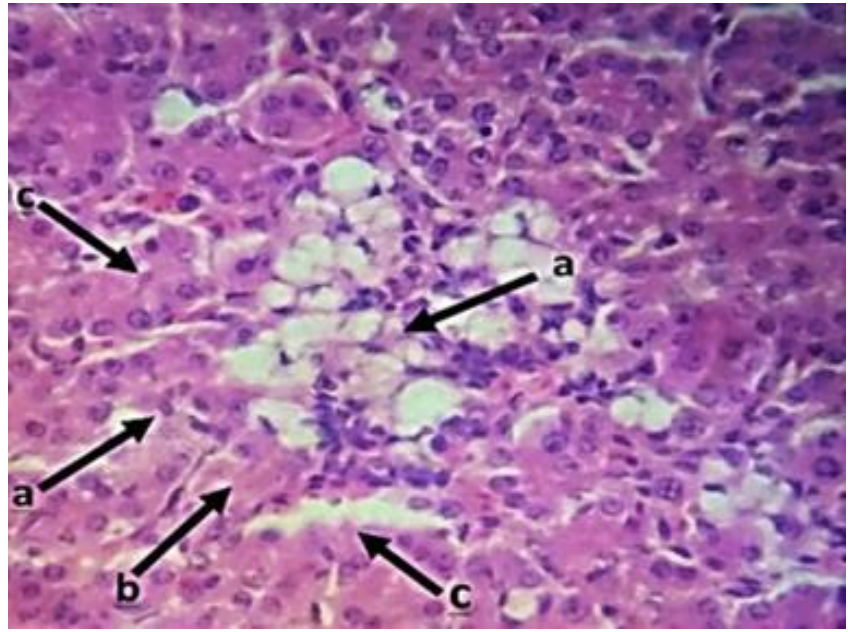

Figure 2: Microscopic examination of liver in chicks treated with lambda-cyhalothrin at dose $22.85 \mathrm{mg} / \mathrm{kg}$ orally from 1-7 days of age show a: fatty changes b: with infiltration of inflammatory cells c: hemorrhage. HE, $40 \times 2.2 \mathrm{X}$. 


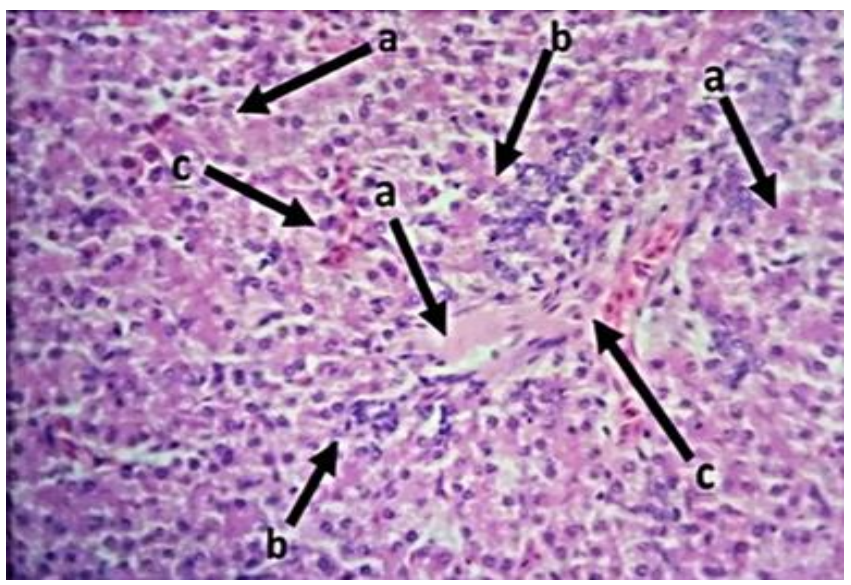

Figure 3: Microscopic examination of liver in chicks treated with $45.7 \mathrm{mg} / \mathrm{kg}$ of lambda-cyhalothrin from 1-7 days of age show a: coagulation necrosis, b: infiltration of inflammatory cells, c: hemorrhage. HE, $40 \times 1.6 \mathrm{X}$.

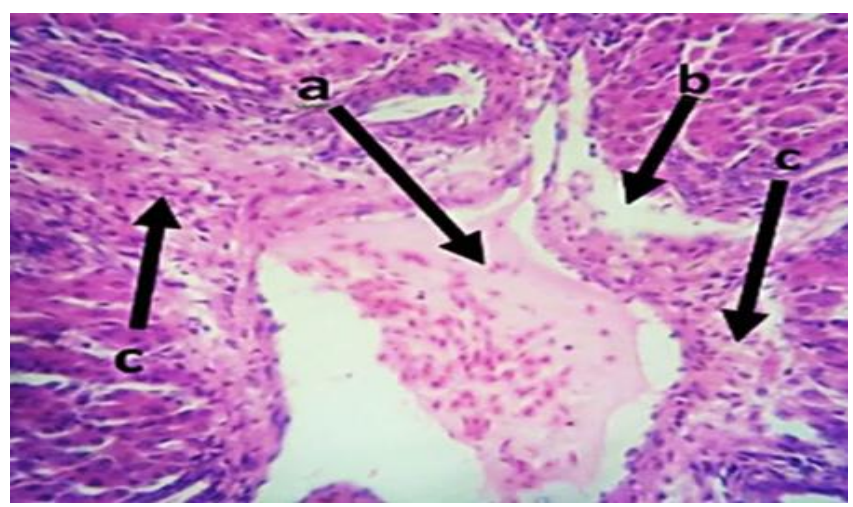

Figure 4: Microscopic examination of liver in chicks treated with lambda-cyhalothrin at dose $11.42 \mathrm{mg} / \mathrm{kg}$ orally from 1 14 days of age show a: recent thrombus, b: vasogenic edema c: vasculitis. HE, $40 \times 1.2 \mathrm{X}$.

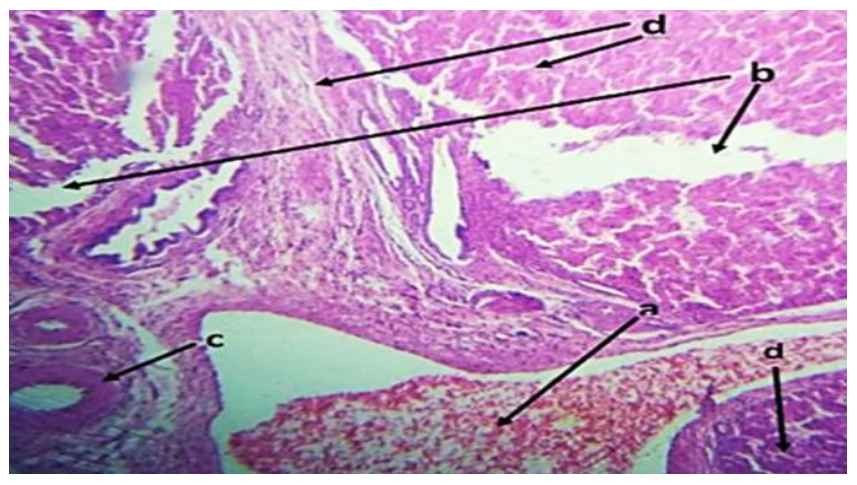

Figure 5: Microscopic examination of liver in chicks treated with lambda-cyhalothrin at dose $11.42 \mathrm{mg} / \mathrm{kg}$ orally from 114 days of age show a: recent thrombus, b: vasogenic edema and c: vasculitis. HE, $40 \times 1.2 \mathrm{X}$.

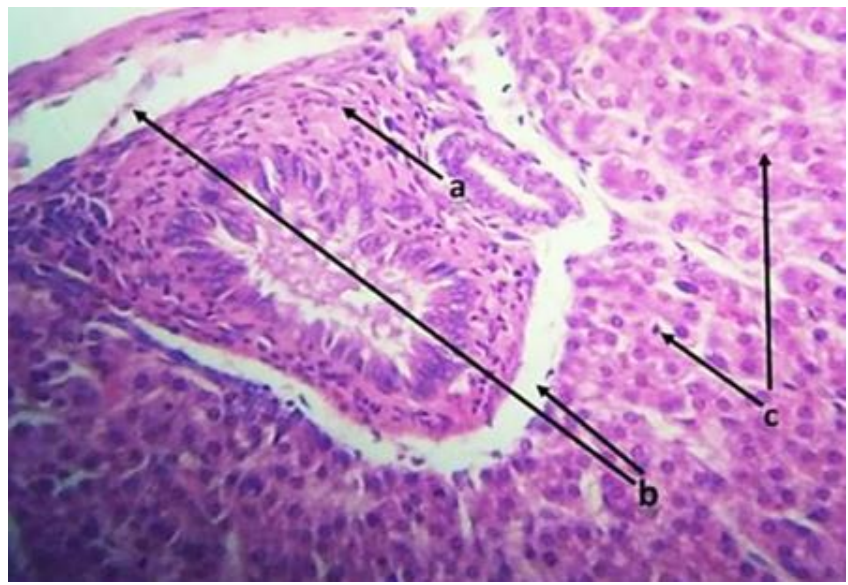

Figure 6: Microscopic examination of liver in chicks treated with lambda-cyhalothrin at dose $22.85 \mathrm{mg} / \mathrm{kg}$ orally from 128 days of age show a: hyperplasia of epithelial of bile duct b: edema c: dilation of sinusoid. HE, $40 \times 1.7 \mathrm{X}$.

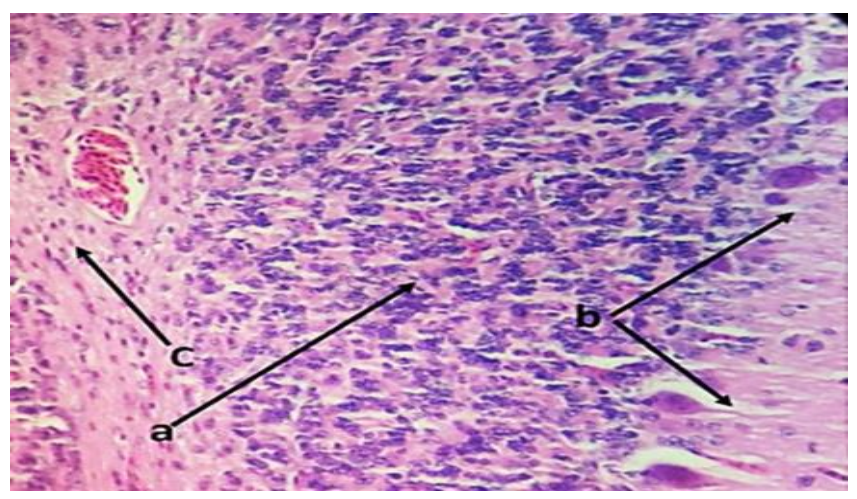

Figure 7: Microscopic examination of brain in chicks treated with lambda-cyhalothrin at dose $11.42 \mathrm{mg} / \mathrm{kg}$ orally from 1-7 days of age show a: shrunken in Purkinje cells b: congestion. HE, $40 \times 1.1 \mathrm{X}$.

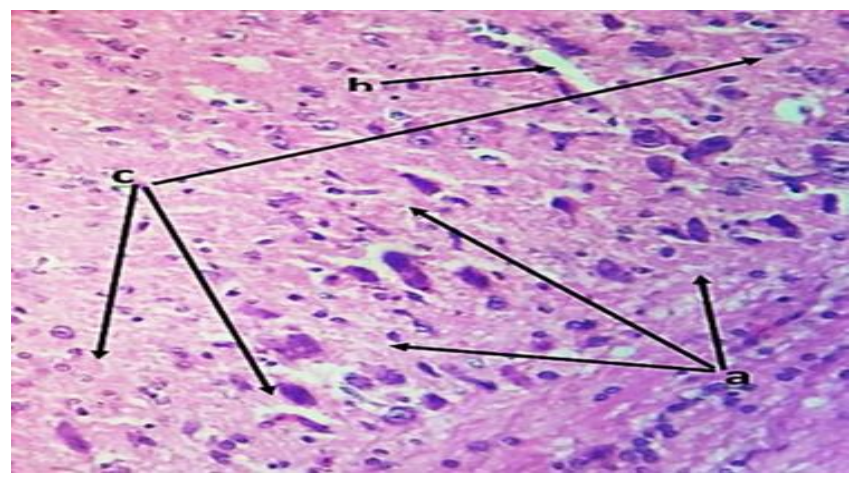

Figure 8: Microscopic examination of brain in chicks treated with lambda-cyhalothrin at dose $11.42 \mathrm{mg} / \mathrm{kg}$ orally from 1-7 days of age a: shrunken of neuronal cell body b: vasogenic edema c: demyelination of axon. HE, 40×1.1X. 


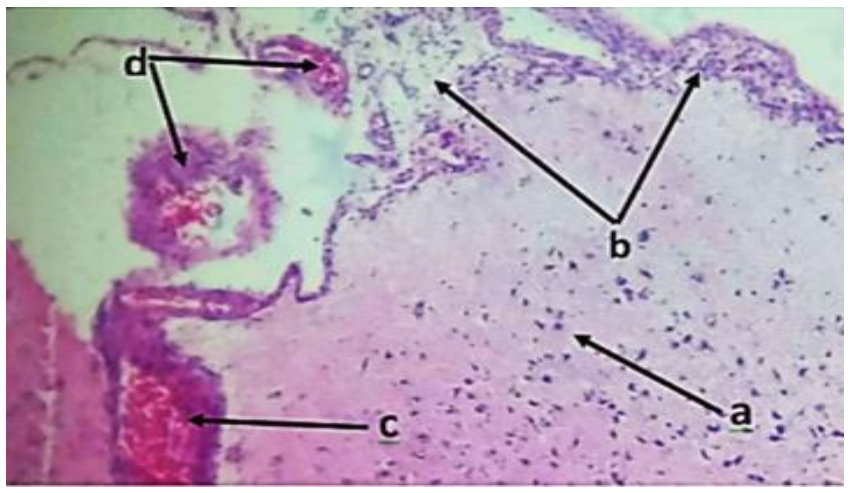

Figure 9: Microscopic examination of brain in chicks treated with $45.7 \mathrm{mg} / \mathrm{kg}$ of lambda-cyhalothrin from 1-7 days of age show a: liquefactive necrosis b: infiltration of inflammatory cells $\mathrm{c}$ : congestion d: necrotizing of blood vessels wall. $\mathrm{HE}, 40 \times 1.4 \mathrm{X}$.

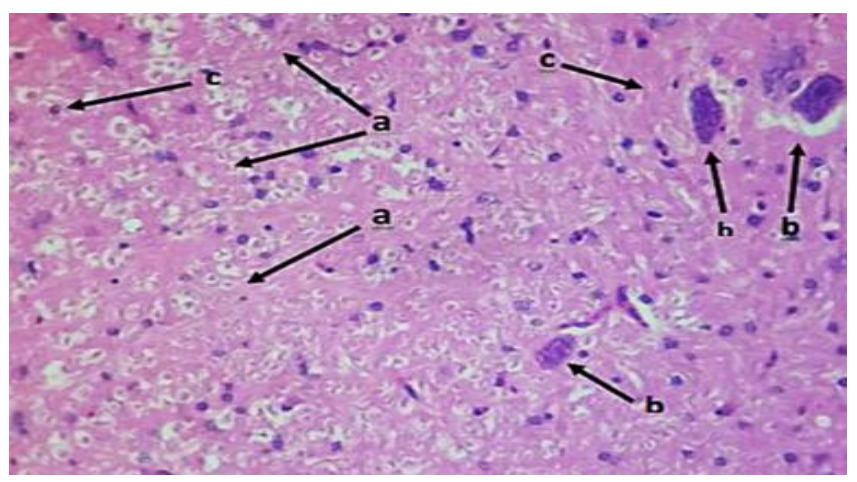

Figure 10: Microscopic examination of brain in chicks treated with $45.7 \mathrm{mg} / \mathrm{kg}$ of lambda-cyhalothrin from 1-7 days of age show a: sever vascular degeneration. HE, $40 \times 2.2 \mathrm{X}$.

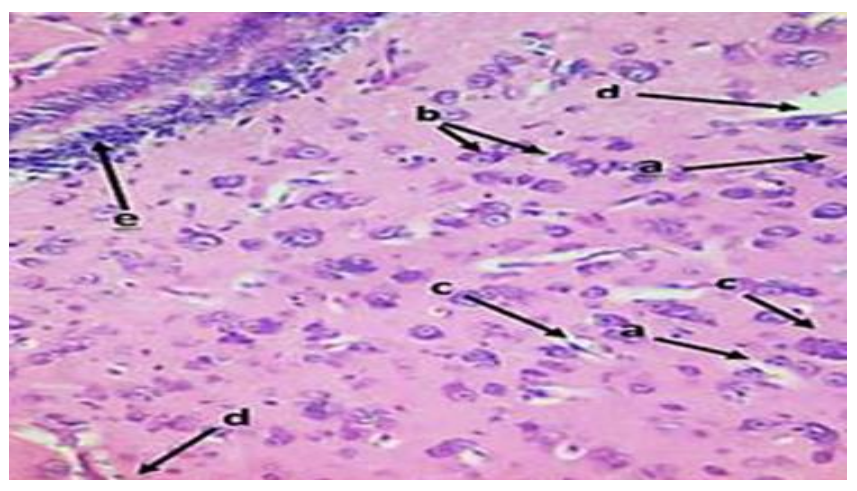

Figure 11: Microscopic examination of brain in chicks treated with lambda-cyhalothrin at dose $11.42 \mathrm{mg} / \mathrm{kg}$ orally from 1-14 days of age show a: hyper atrophy of astrocyte b: proliferation of astrocyte c: demylination of axon d: vasogenic edema e: infiltration of inflammatory cells HE, $40 \times 1.3 \mathrm{X}$.

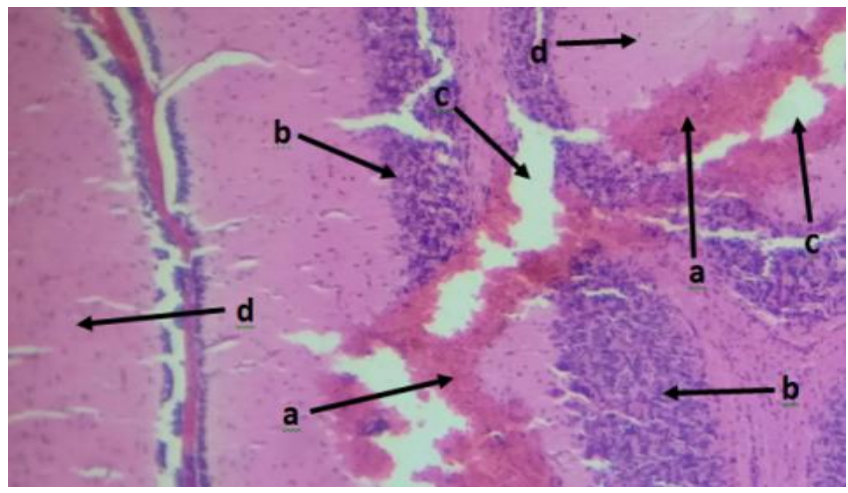

Figure 12: Microscopic examination of brain in chicks treated with lambda-cyhalothrin at dose $22.85 \mathrm{mg} / \mathrm{kg}$ orally from 1-14 days of age show a: patches hemorrhage b: sever infiltration of inflammatory cells c: edema d: liquefactive necrosis HE, 40×2.6X.

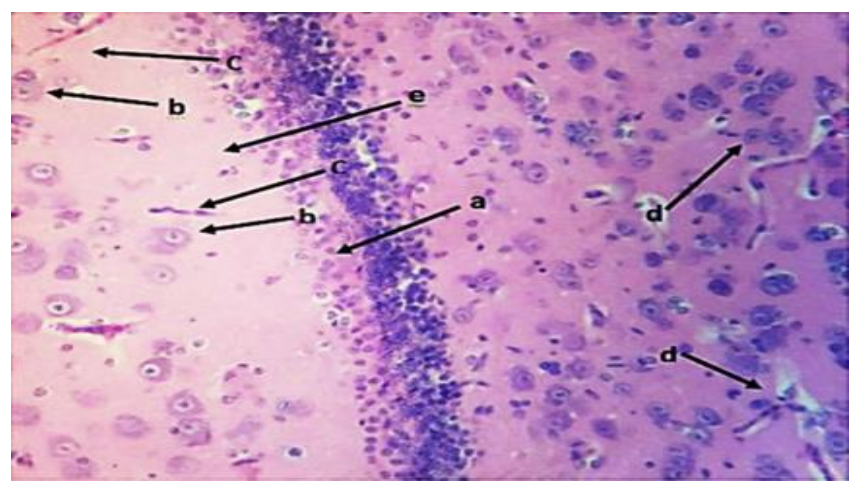

Figure 13: Microscopic examination of brain in chicks treated with $45.7 \mathrm{mg} / \mathrm{kg}$ of lambda-cyhalothrin from 1-28 days of age show a: proliferation of oligodendroglia cells with longitudinal arrangement $b$ : hypertrophy of astrocyte c: demyelination of neuron axon $\mathrm{d}$ : vasogenic edema e: liquefactive necrosis. HE, $40 \times 1.2 \mathrm{X}$.

\section{Discussion}

Due to the broad- spectrum, availability, and low price of lambda-cyhalothrin, and the limited information on the toxicity in avian, the effects of our current study spotlight on the acute and subacute toxicity of lambda-cyhalothrin in the chick's model. The $\mathrm{LD}_{50}$ of lambda-cyhalothrin was $228.5 \mathrm{mg} / \mathrm{kg}$ orally in chicks, while the $\mathrm{LD}_{50}$ in female rats was $56 \mathrm{mg} / \mathrm{kg}$ orally and $79 \mathrm{mg} / \mathrm{kg}$ orally in male rats (19). In mice, the $\mathrm{LD}_{50}$ was $19.9 \mathrm{mg} / \mathrm{kg}$ orally (19), 416.22 $\mathrm{mg} / \mathrm{kg}$ orally (20) in rabbit so that lambda-cyhalothrin is highly toxic in mice and rats and moderately toxic in chicks (19). The signs of acute toxicity estimated in this study such as depression and feathered, closed eyelids, wing drooping, defecation, twisting of the head, gasping and recumbency. While the clinical signs of acute oral neurotoxicity in the rat 
are ataxia, piloerection, salivation, lacrimation, as well as reducedmotor activity (21). Neurotoxicity is the primary acute toxic effect of lambda-cyhalothrin is; it can impair the function of proteins regulating $\mathrm{Na}^{+}$channels. This results in a change in nerve function (10).

Sub-acute doses of lambda-cyhalothrin cause a significant decrease in the weight of chicks compared to the control group in the seventh, fourteenth and twenty-eight days. This result agrees with the study of $(22,23)$. This may be attributed to the toxic effect, which reduces the intake and absorption of nutrients by the gut, and changed efficiency of food conversion rate, according to Ball and Chhabra (24). These results are in consistance with the findings of Yousef $(23,25)$, who observed that treatment with lambda cyhalothrin reduces food consumption and weight gain in male rabbits. Different pyrethroids have been found to alter body weight as a result of exposure to this group of pesticides (26).

Our results revealed, the behavioral and histological changes observed in the liver and brain of chicks represented biomarkers for assessing insecticides toxicity. The values of this study in chicks treated with lambdacyhalothrin at low toxic doses are decreased in open-field activity and increased in the tonic immobility test, especially at the dose $20 \mathrm{mg} / \mathrm{kg}$. These behavioral changes are identical in cases of pyrethroids poisoning in subacute and chronic exposure $(26,27)$ are agreement with the Mustafa and Al-Baggou in mice (28) and, Arulraj et al., (29). In fish tilapia, whereas increase activity and rapid swimming were reported by (29). The direct effect of the pesticide with interference of oxygen uptake and reducing brain cell respiration may be reason for damages seen in the brain (30). Furthermore, studies have proven the (CNS) central nervous system is the target organ of pyrethroids. Due to its high oxygen uptake, high pool of polyunsaturated fatty acids, and low levels of anti-oxidant mechanisms (31).

The most critical systemic effect of lambda-cyhalothrin was decreased motor activity. Pyrethroids insecticides are lipophilic in composition, which is absorbed via the (GIT), but also may incorporate into lipid-rich internal tissues, including body fat and the skin, liver, kidneys, ovaries, and nervous systems (32). The present results indicate that lambda-cyhalothrin causes hepatotoxicity with sub-acute toxicity. The histological sections of the liver treated with lambda-cyhalothrin insecticide show congestion, fatty changes, infiltration of inflammatory cells, coagulative necrosis, vasogenic edema and hyperplasia of epithelial sinusoid these results agree with the previous study in a rat of Fetoui et al. $(32,33)$ in mice and Basir et al. (34) reported similar effects of the liver treated with lambda-cyhalothrin in rabbit and in fish. They suggested that oxygen free radicals and oxidative damage impact the pathogenesis of liver damage by elevating lipid peroxidation and reducing the activity of antioxidants (35). In addition, lambdacyhalothrin induced hepatotoxicity in freshwater tilapia through its membrane destabilizing properties and peroxidation activities (36). Other pyrethroids, such as alpha-cypermethrin, induced the parenchymatous degeneration of hepatocytes in Swiss mice (26).

Sections of the brain treated with LCT show shrunken in purkinji cells, congestion, vasogenic edema, demyelination of axon, liquefactive necrosis and infiltration of inflammatory cells and hypertrophy of astrocytes. Similar histopathological changes observed in the brain of mice treated with lambda-cyhalothrin by (36) and in rats (37). They reported tissue damage in the brain and liver, which might be due to the effect of reactive oxygen species (ROS) generated during insecticide metabolism $(36,37)$.

\section{Conclusion}

Lambda-cyhalothrin has a moderate toxic effect in chicks, and causes behavioral and histological toxic effects, especially with high dose and exposure period (sub-acute). Therefore, we do not recommend using this insecticide and restricted application of lambda-cyhalothrin in homes and agriculture is suggested.

\section{Acknowledgement}

Our study was supported by the College of Veterinary Medicine, University of Mosul, and Mosul, Iraq.

\section{Conflict of interest}

The authors financial claim does not have any interest.

\section{References}

1. Amweg EL, Weston DP. Use and toxicity of pyrethroid pesticides in the Central Valley, California, USA. Environ Toxicol Chem. 2006;24:1300-1301. DOI: 10.1897/04-146r1.1

2. Turgut $\mathrm{C}$, Ornek H, Cutright TJ. Determination of pesticide residues in Turkey's table grapes: The effect of integrated pest management organic farming, and conventional farming. Environ Monit Assess. 2011;173:315-323. DOI: $10.1007 / \mathrm{s} 10661-010-1389-4$

3. Shen MF, Kumar A, Ding SY, Grocke S. Comparative study on the toxicity of pyrethroids, $\alpha$-cypermethrinand deltamethrin to Ceriodaphnia dubia. Ecotoxicol Environ Safe. 2012;78:9-13. DOI: 10.1016/j.ecoenv.2011.07.018

4. Anadon A, Martinez M, Martinez MA, Diaz MJ. Martinez Larranaga MR. Toxicokinetics of lambda-cyhalothrin in rats. Toxicol Lett. 2006;165:47-56. DOI: 10.1016/j.toxlet.2006.01.014

5. Ratnasooriya WD, Ratnayake SS, Jayatunga YN. Effects of Icon, a pyrethroid insecticide on early pregnancy of rats. Hum Exp Toxicol. 2003;22:523-533. DOI: 10.1191/0960327103ht381oa

6. Barata C, Baird DJ, Nogueira AJ, Soares AM, Riva MC. Toxicity of binary mixtures of metals and pyrethroid insecticides to daphnia magna straus. Aquat Toxicol. 2006;78:1-14. DOI: 10.1016/j.aquatox.2006.01.013

7. Schroer AF, Belgers JD, Brock TC, Matser AM, Maund SJ, Van den Brink PJ. Comparison of laboratory single species and field population-level effects of the pyrethroid insecticide lambda cyhalothrin on freshwater invertebrates. Arch Environ Contam Toxicol. 2004;46:324-335. DOI: 10.1007/s00244-003-2315-3 
8. He L, Troiano J, Wang A, Goh K. Environmental chemistry, ecotoxicity, and fate of lambda-cyhalothrin. Rev Environ Contam Toxicol. 2008. DOI: 10.1007/978-0-387-77030-7_3

9. Sankar P, Telang AG, Manimaran A. Protective effect of curcumin on cypermethrin-induced oxidative stress in Wistar rats. Experi Toxicol Pathol. 2012;64(5):487-493. DOI: 10.1016/j.etp.2010.11.003

10. Agency for Toxic Substances and Disease Registry (ATSDR). Toxicological profile for pyrethrins and pyrethroids. 2003; [available at]

11. Dixon WJ. Efficient analysis of experimental observations. Ann Rev Pharmacol Toxicol. 10.1146/annurev.pa.20.040180.002301

12. Al-Baggou BK, Mohammed FK. Antagonism of methomyl-induced toxicosis by diphenhydramine in rats. Envir Toxicol Pharmacol. 1999;7:119-125. [available at]

13. Naser AS, Mohammad FK. Central depressant effects and toxicity of propofol in chicks. Toxicol Rep. 2014;562-568. DOI: 10.1016/j.toxrep.2014.08.003

14. Al-Abdaly YZ, Al-Hamdany EK, Abed ER. Toxic effects of butylated hydroxytoluene in rats. Iraqi J Vet Sci. 2020;35(1):121-128. DOI: 10.33899/ijvs.2020.1264351.1322

15. Mousa YJ, Al-Zubaidy MH, Amin SM. Age-related anesthetic of ketamine in the chickens. Iraqi J Vet Sci. 2021;35(3):1-10. DOI: 10.33899/ijvs.2020.127100.14558

16. Shaban KA, Ibrahim MH, Faris GA. Evaluation of the antinociceptive effect of xylazine and it's interaction with metoclopramide in the acute pain model in mice. Iraqi J Vet Sci. 2020;34(2):383-388. DOI: 10.33899/ijvs.2019.126070.1226

17. Al-Abdaly YZ, Saeed MG, Al-Hashemi. Effect of methotrexate and aspirin interaction and its relationship to oxidative stress in rats. Iraqi J Vet Sci. 2021;35(1).151-156. DOI: 10.33899/ijvs.2020.126490.1335

18. Petrie AP, Watson. Statistics for veterinary and animal science. Oxford: Blackwell Science; 2013. 90-140 p. DOI: $10.1136 /$ vr.f7415

19. United States Environmental Protection Agency (USEPA). Memorandum, Cyhalothrin and lambda-cyhalothrin $-4^{\text {th }}$ report of the Hazard Identification Assessment Review Committee, USEPA Health Effects Division, Report dated September 12, 2002. [available at]

20. Ashraf MM, Ahmed HO. Immunotoxic effects of lambda-cyhalothrin in rabbits. J Egypt Soc Toxicol. 2007;36:23-33. [available at]

21. Oularbi HKH. Biochemical and histopathological changes in the kidney and adrenal gland of rats following repeated exposure to lambda-cyhalothrin. J Xeno. 2014;4:2240. DOI: 10.4081/xeno.2014.2240

22. Ball LM, Chhabra RS. Intestinal absorption of nutrients in rats treated with 2, 3, 7, 8- tetrachlorodi benz-p-dioxin (TCDD). J Toxicol Environ Health. 1981;8:629-36. DOI: 10.1080/15287398109530097

23. Yousef IY, Vitamin E. Modulates reproduc- tive toxicity of pyrethroid lambda- cyhalothrin in male rabbits. Food Chem Toxicol. 2010;48:1152-9. DOI: 10.1016/j.fct.2010.02.002

24. Prasanthi K, Muralidhara PS, Rajini K. Fenvalerate-induced oxidative damage in rat tissues and its attenuation by dietary sesame oil. Food Chem Toxicol. 2005;43:299-306. DOI: 10.1016/j.fct.2004.10.005

25. Aouey B, Derbali M, Chlourou y, Bouchard M, Khabir A, Fetoui H. Pyrethroid insecticide lambda-cyhalothrin and its metabolites induce liver injury through the activation of oxidative stress and proinflammatory gene expression in rats following acute and subchronic exposure. Environ Sci Pollut Res. 2017;24:5841-5856. DOI: $10.1007 / \mathrm{s} 11356-016-8323-4$

26. Luty S, Latuszynska J, Obuchowska D, Tokarska M, Haratym-Maj A. Subacute toxicity of orally applied alphacypermethrin in Swiss mice. Ann Agri Environ Med. 2000;7(1):33-41. [available at]

27. Righi DA, Palermo-Neto J. Effects of type II pyrethroids cyhalothrin on peritoneal macrophage activity in rats. Toxicol. 2005;212:98-106. DOI: $10.1016 / j . t o x .2005 .04 .004$

28. Mustafa KA, Al-Baggou BK h. Toxicological and neurobehavioral effects of chlorpyrifos and deltamethrin insecticides in mice. Iraqi $\mathbf{J}$ Vet Sci. 2020;34(1):189-196. DOI: 10.33899/ijvs.2019.125738.1144

29. Arulaj JS, Padmavathy p, Srinivasan A, Sugumar G, Jawahar P. Acute toxicity of lamda-cyhalothrin and the histopathological changes of gill and liver tissues of Tilapia (Oreochromis niloticus). J Coast Res. 2019;86:235-238. DOI: 10.2112/SI86-034.1

30. Samson FE, Nelson SR. The aging brain, metals and oxygen free radicals. Cell Mol Biol. 2000;46:699-707. [available at]

31. Soderlund DM, Clark JM, Sheets LP, Mullin LS, Piccirillo VJ, Sargent D, Stevens JT, Weiner ML. Mechanisms of pyrethroid neurotoxicity: Implications for cumulative risk assessment. Toxicol. 2002;171:3-59. DOI: 10.1016/s0300-483x(01)00569-8

32. Fetoui H, Garoui EM, Zeghal E. Lambda-cyhalothrininduced biochemical and histopathological changes in the liver of rats: Ameliorative effect of ascorbic acid. Exp Toxicol Pathol. 2009;61:189-196. DOI: 10.1016/j.etp.2008.08.002

33. Al-Sarar AS, Abobakr Y, Bayoumi AE, Hussein HI, Al-Ghothemi M. Reproductive toxicity and histopathological changes induced by lambda-cyhalothrin in male mice. Environ Toxicol. 2012;1-18. DOI: 10.1002/tox.21802

34. Basir A, Khan A, Mustafa R, Khan MZ, Rizvi F, Mahmood F, Yousaf A. Toxicopathological effects of lambda-cyhalothrin in female rabbits (Oryctolagus cuniculus). Hum Exp Toxicol. 2011;30:591-602. DOI: $10.1177 / 0960327110376550$

35. Parthasarathy R, Joseph J. Study on the changes in the levels of membrane-bound ATPases activity and some mineral status in $\mathrm{k}$ cyhalothrin-induced hepatotoxicity in fresh water tilapia (Oreochromis mossambicus). Afr J Environ Sci Technol.2011;5:98103. [available at]

36. Pawar NN, Prarabdh ChB, Laxman PSh, Avinash GT, Karam PS. Oxidative impairment and histopathological alterations in kidney and brain of mice following subacute lambda-cyhalothrin exposure. Toxicol Indust Health. 2016;1-10. DOI: 10.1177/0748233715627736

37. Sankar P, Telang AG, Manimaran A. Protective effect of curcumin on cypermethrin-induced oxidative stress in Wistar rats. Experimen Toxicol Pathol. 2012;64:487- 493. DOI: 10.1016/j.etp.2010.11.003

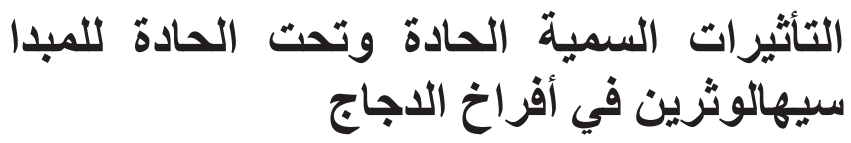

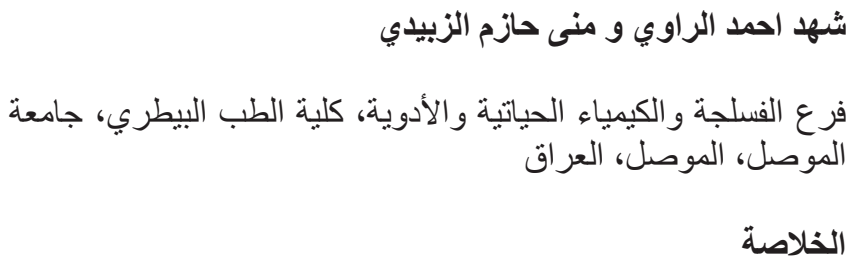

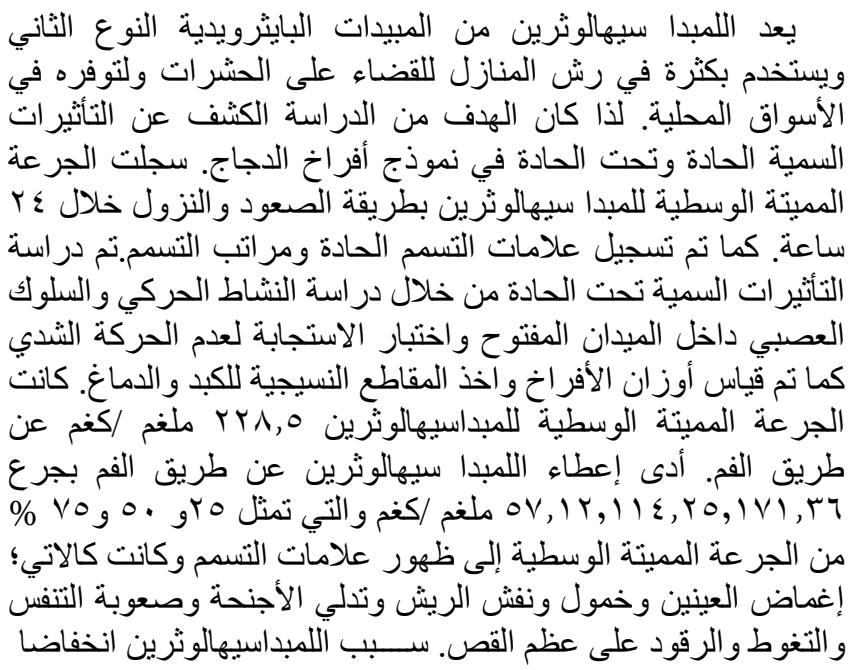




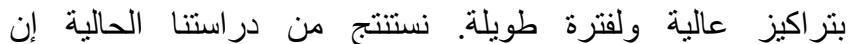

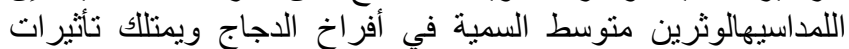

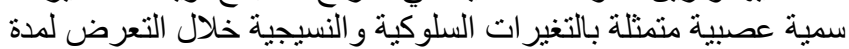
ر ب يوم تحت الحادة. لذا نتصح بالحد من بن استخدامه في المنازل

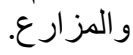

معنويا في أوزان الأفراخ وقلة في الحركة داخل الميدان المفتوح

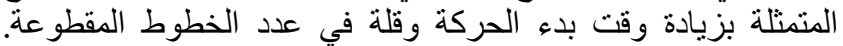

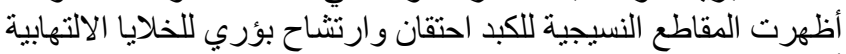

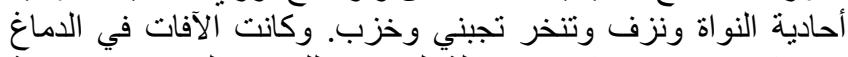

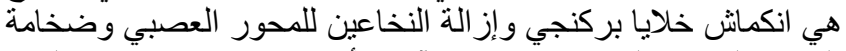
الخلايا النجمية العصبية وكانت الآفات أكثر شدة عند استخدام المبيد 